Rapid Reviews COVID-19

\title{
Reviews of "Prisons and Pandemics"
}

\section{Lauren Lyons $^{1}$, Natalie Pifer ${ }^{2}$}

${ }^{1}$ Rutgers University, ${ }^{2}$ University of Rhode Island, Criminology and Criminal Justice

Published on: Aug 11, 2020

DOI: $10.1162 / 2 \mathrm{e} 3983 f 5.7 b 95 b 8 \mathrm{e} 0$

License: Creative Commons Attribution 4.0 International License (CC-BY 4.0). 
To read the original manuscript, click the link above.

Summary of Reviews: This is a worthwhile contribution that effectively lays out epidemiological, legal, and moral arguments relevant to prisons in the new context of COVID-19. It should be read widely.

Reviewer 1 (Lauren Lyons) | प्र०००

Reviewer 2 (Natalie Pifer) |

\section{RR:C19 Strength of Evidence Scale Key}

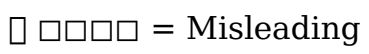

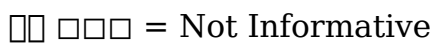

प्रा पि = Potentially Informative

प्राप्र = Reliable

प्राप्र = Strong

To read the reviews, click the links below. 